\title{
How Citizens Interact with Their Government and Why We Care
}

Nancy C. Roberts, ed., The Age of Direct Citizen Participation (New York: M. E. Sharpe, 2008). 520 pp. ISBN: $9780765615121, \$ 89.95 ;$ ISBN: 9780765615138, \$39.95 paper.

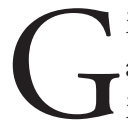
iven the potential advantages and pitfalls associated with citizen participation in governing decisions, this is an increasingly important area for academic research and one that is equally important for practitioners to understand. Not only does research in this field teach us if, when, and how citizens attempt to influence their government through direct participation, but also we come to understand the effects, both positive and negative, of such involvement.

What we do know about citizen participation raises important questions. First, how has citizen participation in governance been viewed historically? Next, do citizens actually choose to participate in governing, and who are these citizens? Third, how do they choose to participate, if they do? Fourth, does any of this participation actually matter to governance, and if so, how? Finally, is this picture of involvement changing over time? The Age of Direct Citizen Participation answers these important questions, but only in part.
Nancy Roberts's contribution to the ASPA Classics series, The Age of Direct Citizen Participation, provides a compilation of the preeminent works in the field of citizen participation as it relates to the administrative affairs of the state. The book begins by providing an overview of what citizen participation includes and how it historically has been defined and regarded. Roberts builds the volume by constructing a clear historical context for participation research. The synthesis and categorization of the definitions of citizen participation in democracies is well constructed and simple enough even for those who are not participation experts to understand. Roberts clearly explains the differences between views of citizen participation as a legal, ethical, or sociological construct. Whether participation is a legal right or a moral imperative is an important starting point from which the reader can then proceed to understand this field of research.

The introduction to the second part of the book provides a clear primer on the important question of whether citizens are subjects, customers, partners, or owners of the bureaucratic state. Roberts's synthesis clearly sets the stage for readers to understand the purpose and context of the body of research presented. The reader comes to understand that different writers have
Deserai Anderson Crow is an assistant professor in the School of Journalism and Mass Communication at the University of Colorado at Boulder, where she is also associate director of the Center for Environmental Journalism. Her research interests include citizen involvement and mass media influence in environmental policy. She earned her doctorate in 2008 from Duke University's Nicholas School of the Environment and Earth Sciences. E-mail: deserai.crow@colorado.edu 
different viewpoints associated with the role of citizens in governance. The inclusion of articles that address the key disagreements in this scholarly debate effectively sets the stage for the following two parts of the book, which cover how citizens can be involved in governing decisions both in terms of arenas and mechanisms.

The state of the research, focusing on arenas and mechanisms for direct citizen participation and assessments of that participation, makes up the bulk of the text. Particularly effective is the typology that Roberts uses to define participation along individual and group schematics. She divides participation into four classes: individual, small group, large group, and electronic. The idea behind these divisions is that the problem of scale is one of the most significant problems encountered when attempting to understand citizen participation. This is not an altogether perfect typology, as individuals and groups likely can undertake the same modes of participation with similar consequences. Perhaps a more effective typology would break the forms of participation down into their forum characteristics - her fourth category of electronic participation is an excellent example. Public meetings, electronic participation, letter writing, and other modes of participation likely have varying effects and require different resources and motivations on the part of the citizen. The use of these modes of participation in some manner may provide the foundation for a more effective framework to help the reader understand participation differences among citizens. Roberts's actual typology does, however, allow the reader to understand some of the important differences in participation research.

Finally, the important emerging issues in the field and directions for future research are outlined. These articles establish a strong foundation on which the reader can attempt to understand assessments of citizen participation in the field. Roberts concludes the volume with a well-written and well-compiled chapter on the future direction of citizen participation research that provides further insights into the broader context of this book.

The later chapters related to assessment and theory building are not as strong as the earlier chapters in terms of the series' goal to be a tool for general reference. While they certainly include some of the most important articles in the field, they also include a significant amount of overly technical research that limits the effectiveness of the chapters to speak to a broad and nonexpert audience. Roberts does, however, compensate for the technical articles by providing well-written introductions at the beginning of each part of the book. These allow the reader to follow the technical scholarship to a much greater degree than would otherwise be possible for novices in the field. This critique is offered with an understanding that attempting to balance the needs of researchers and practitioners is not easy to achieve in a single volume.
The articles chosen for this compilation are varied, both from a methodological perspective and from a theoretical perspective. This is particularly effective when attempting to assemble a list of important works in a field as disparate as citizen participation. The most significant contributions in this volume are those that provide the reader with an understanding of the direction in which this field is moving, specifically as it relates to the challenges that technology introduces. Andrew Kakabadse, Nada K. Kakabadse, and Alexander Kouzmin's article, "Reinventing the Democratic Governance Project through Information Technology? A Growing Agenda for Debate," provides a solid understanding of the growing electronic modes of participation and their influences on governance. Additionally, articles by Clayton Thomas ("Public Involvement in Public Management: Adapting and Testing Borrowed Theory"); Lawrence C. Walters, James Aydelotte, and Jessica Miller ("Putting More Public in Policy Analysis"); and Eran Vigoda ("From Responsiveness to Collaboration: Governance, Citizens, and the Next Generation of Public Administration") all provide important insights into emerging theories of direct citizen participation.

Also effective are the articles in part 3 that clearly and effectively discuss the appropriate roles for citizens in the administrative state. The articles chosen often provide concrete advice, so as to make the volume somewhat useful to the practitioner as well as the academic. This is especially true of some pieces in the section on assessment of citizen participation, including articles by Judy B. Rosener ("Citizen Participation: Can We Measure Its Effectiveness?" and "Making Bureaucrats Responsive: A Study of the Impact of Citizen Participation and Staff Recommendations on Regulatory Decision Making"); David M. Austin ("Resident Participation: Political Mobilization or Organization Co-optation?”); and Cheryl Simrell King, Kathryn M. Feltey, and Bridget O'Neill Susel ("The Question of Participation: Towards Authentic Public Participation in Public Administration"). These articles collectively tell the practitioner-reader what works and what does not work when engaging citizens in governance.

While this volume is an important contribution to the field of citizen participation and a necessary compilation of important works in the field, it also leaves the reader without knowledge in some areas. After reading this book, the reader takes away a clear understanding of the significant contributions to the field of citizen participation in bureaucratic governance. The broader understanding of how this relates to citizen participation in democratic governance, however, is lacking in depth. The significant chasm between public administration research and political science research is highlighted when reading this volume. This unfortunate gap is not unique to this volume, but nonetheless it is important to note here. By limiting this text only to 
material that relates to administration, the audience for this book is significantly limited. By providing more depth and context relating this subfield of participation research to the broader and well-known field of participation research in political science, this book would provide more useful insights into the field of citizen participation. Additionally, providing an understanding of how this literature differs from the broader political science literature also would provide the reader with important knowledge. This could have been done effectively by providing a more thorough introduction to the volume-specifically, by providing information about participation gaps (by socioeconomic status, race, and gender, for example).

The reader needs to understand who participates and how much. Otherwise, the reader is left with the impression that citizen participation is widespread and highly significant to governance. While such expansive participation may be a normative democratic value, much research disputes this assumption (e.g., Brady, Verba, and Schlozman 1995; Verba and Nie 1972; Verba et al. 1993). Previous research on citizen participation in democratic governance and administration tells us that citizens often choose not to be involved in governing decisions (e.g., Verba, Schlozman, and Brady 1995), and when they do get involved, they often have only limited knowledge with which to undertake participatory activities (Delli Carpini and Keeter 1996). Citizens frequently refrain from participating in governing decisions unless they are encouraged by others to do so. It is important for the reader to understand that much participation is motivated by mobilization efforts, not simply by individual will (Rosenstone and Hansen 1993).

The difficulties of effectively covering an entire field of inquiry in a single edited volume are present in this volume, but are not unique to it. At times, the sections of this book focus on the deliberative process of participation, and at other times, they focus more specifically on administrators soliciting citizen input.

To understand how these chapters fit together, a more complete description of citizen participation is needed. In addition to providing a more thorough explanation of when and how participation takes place, it is also important to define what is meant by participation. Roberts provides a solid description of legal and ethical concepts of participation. Beyond this, it would be helpful to provide some sort of spectrum of what constitutes participation (attending public meetings, writing letters, voting).

Finally, this book is marketed as appropriate for students in public administration and public management courses. Students in professional programs, such as the master of public administration, would not likely find this volume accessible and relevant to their generalist courses. It is, however, highly relevant and appropriate for researchers and doctoral students. The highlights of this volume include its ability to synthesize the vast field of participation research related to public administration. This volume is a very useful resource for students and researchers who strive to understand the emerging and changing field of citizen participation. While it does not provide the degree of insight that it would need to be a stand-alone volume of citizen participation research, it does provide a thorough compilation of relevant administrative articles.

Roberts effectively answers four of the five questions outlined at the start of this review. Her edited volume clearly teaches the reader the historical perspective and importance of citizen participation in administrative decisions. It also discusses the methods of participation that citizens choose, through her individualgroup participation typology, although a more complete rubric would help the reader understand the many avenues of citizen participation. The concluding sections of this book clearly outline when citizen participation is effective and the changing dynamics of this participation. The book, however, leaves one question unanswered: do citizens actually decide to participate in significant numbers, and which citizens choose to do this? This question is vital to understanding the gaps in participation and the resulting consequences of these participation gaps. It is clear from political science research that highly educated, white, affluent citizens participate at higher levels than other demographic groups. While the focus of these participation gap effects is often related to electoral consequences, this volume could benefit from the inclusion of research that discusses the consequences of any gaps in participation on bureaucratic outcomes.

\section{References}

Brady, Henry E., Sidney Verba, and Kay Lehman Schlozman. 1995. Beyond SES: A Resource Model of Political Participation. American Political Science Review 89(2): 271-94.

Delli Carpini, Michael X., and Scott Keeter. 1996. What Americans Know about Politics and Why It Matters. New Haven, CT: Yale University Press.

Rosenstone, Steven J., and John Mark Hansen. 1993. Mobilization, Participation, and Democracy in America. New York: Macmillan.

Verba, Sidney, and Norman H. Nie. 1972. Participation in America: Political Democracy and Social Equality. Chicago: University of Chicago Press.

Verba, Sidney, Kay Lehman Schlozman, and Henry E. Brady. 1995. Voice and Equality in American Politics. Cambridge, MA: Harvard University Press.

Verba, Sidney, Kay Lehman Schlozman, Henry E. Brady, and Norman H. Nie. 1993. Citizen Activity: Who Participates? What Do They Say? American Political Science Review 87(2): 313-14. 